\title{
Study on Pudina (mint) arka prepared by three different methods
}

\author{
Research Article
}

\section{Shweta Paul $^{1 *}$, Karunanidhi Sharma ${ }^{2}$, Parimi Suresh ${ }^{3}$}

\section{Consultant, Shree Vishwapranda Ayurvedic Chikitsalya \& Panchakarma center, Yermala, Kallam, Osmanabad, Maharashtra. \\ 2. Research officer, Multani Pharmaceutical Ltd., New Delhi.}

3. Professor, PG Department of Rasashastra \& Bhaishajya Kalpana, National Institute of Ayurveda, Jaipur.

\begin{abstract}
Mint or Pudina (Meantha spicata L) is very common home herb, used in kitchen and also as a home remedy to treat common abdominal problems. It has an important place in Ayurveda and Unani system of medicine. Its juice, paste, powder, extract, distillate are used individually or as ingredient in many formulations to treat stomachache, dyspepsia, indigestion etc. Since it's having volatile oil as important constituent, so Arka is most efficient dosage form to use it. There are conflicts in method of preparation among Arka Prakash (AP), Ayurveda Formulary of India (AFI) and National Formulary of Unani Medicine (NFUM). To evaluate the best method among them the present study has been planned. 3 Samples of Pudina Arka were prepared by following these references using simple distillation method. Method of Arka Prakash was found impractical and difficult to extract Arka. Both the remaining references was found suitable for preparation. The method mentioned in NFUM is found most suitable.
\end{abstract}

Keywords: Arq-e-Pudina, Distillate of Mint, Arka Kalpana.

\section{Introduction}

Mint is a very commonly used herb in kitchen as part of food, as flavoring and at the same time it is also used as home remedy for abdominal problem, for mouth freshener. It is also well described drug in Ayurveda and Unani System of medicine, In both the system important therapeutic values of Mints has been mentioned (1),(2) Where is it useful in Stomachache, Dyspepsia, Indigestion, Aruchi, Krimi, etc. Generally it is used in Kalka (Paste), Choorna (Powder), Swarasa (Juice), Phant, Taila (Oil) and Arka (distilled mint water) dosage form. Among all these, Arka is a preparation, which is very palatable to use, where it overcome its taste and it is much easier to take than powder, paste etc. In Ayurvedic text Pudina Arka is indicated in Chhardi (Vomiting), Ajeerna (Indigestion), Adhamaana (Flatulence), Udarshoola (Stomachache) and Mandagni (digestive impairment) etc(3). In Unani system of medicine also, same types of indications of Pudina Arka are mentioned (4). As per various classics methods of preparations are different in various

*Corresponding Author:

\section{Shweta Paul,}

Consultant, Shree Vishwapranda Ayurvedic

Chikitsalya \& Panchakarma center,

Yermala, Kallam,

Osmanabad, Maharashtra.

E-mail: shreevishvapranda@gmail.com text, where ratio of raw drug, water and distillate (Arka) is different, It is the need of the time to select a perfect and best method by which best quality of $A r k a$ can be obtained. So considering this purpose the present study has been planned, where the methods of Arka Prakash(5) (an Ayurveda classical book which is specially dedicated to Arka Kalpana), Ayurveda Formulary of India(6), and National Formulary of Unani Medicine(7) were taken to evaluate the best and convenient method.

\section{Methodology}

Pudina (mint; Meantha viridis) leaves were collected from Herbal garden, National Institute of Ayurveda, Jaipur. Distilled water was taken from Drug testing laboratory, Department of Rasashastra \& Bhaishajya Kalpana, National Institute of Ayurveda, Jaipur.

Instruments used: Round bottom flask, heating mantle, Condenser, Receiver Flask, Rubber tube. Stands, Clamps etc.

Pudina leaves were collected and washed with tap water.

Clean leaves were analyzed to test its authenticity in the Drug testing laboratory, Department of Rasashastra \& Bhaishajya Kalpana, NIA, Jaipur.

The drug was tested for Macroscopic, Microscopic and Physico- chemical parameters and were compared with standards mentioned in Ayurvedic Pharmacopeia of India(8). 
Table No.1 showing the characters of mint (standards and observed results)

\begin{tabular}{|c|c|c|c|}
\hline S.No. & Physico-chemical parameter & API standards & Sample (Analyzed) \\
\hline 1. & Foreign matter (Total $\%)$ & Not more than $2 \%$ & $2 \%$ (in Ariel parts) \\
\hline 2. & $\mathrm{pH}(10 \%$ aqueous solution) & Not mentioned & 8.1 \\
\hline 3. & Total Ash $(\% \mathrm{w} / \mathrm{w})$ & Not more than $14 \%$ & 13.2 \\
\hline 4. & Acid insoluble ash $(\% \mathrm{w} / \mathrm{w})$ & Not more than $4 \%$ & 4 \\
\hline 5. & Water soluble extractive $(\% \mathrm{w} / \mathrm{w})$ & Not less than $7 \%$ & 2.5 \\
\hline 6. & Alcohol soluble extractive $(\% \mathrm{w} / \mathrm{w})$ & Not less than $2 \%$ & 0.7 \\
\hline 7. & Volatile oil $(\% \mathrm{v} / \mathrm{w})$ & Not less than $0.2 \%$ & \\
\hline
\end{tabular}

Three samples of Arka were prepared by following the reference of Arka Prakash(9), Ayurveda formulary of India (11) and National Formulary of Unani medicine (12) where in all these references ratio and quantity of Pudina leaves, water (taken) and Arka (Distillate) are different as mentioned in Table.

Table No. 2 showing the ratio of Mint, water and distillate according to AP, AFI \& NFUM

\begin{tabular}{|l|c|c|c|}
\hline \multirow{2}{*}{ Reference } & \multicolumn{2}{c|}{ Ratio of Pudina leaves, water and Arka } \\
\cline { 2 - 4 } & Pudina leaves & Water taken & Arka (Distillate) \\
\hline Arka Prakash & 1 & $\begin{array}{c}1 / 100^{\text {th }} \text { Part [for } \\
\text { Sinchana } \\
\text { (sprinkling) }\end{array}$ & $\begin{array}{c}\text { Not mentioned. [Till } \\
\text { Prashsta Arka } \text { Obtained } \\
(10)]\end{array}$ \\
\hline Ayurveda formulary of India & 1 & 15 & 6 \\
\hline National Formulary of Unani Medicine & 1 & 20 & 8 \\
\hline
\end{tabular}

Table no. 3 showing the quantity of mint, water and Arka according to AP, AFI \& NFUM

\begin{tabular}{|l|c|c|c|}
\hline \multirow{2}{*}{ Reference } & \multicolumn{3}{c|}{ Quantity of } \\
\cline { 2 - 4 } & Pudina leaves & Water taken & Arka (Distilled upto) \\
\hline Arka Prakash & $32 \mathrm{gm}$ & QS (Sprinkled) & - \\
\hline Ayurveda formulary of India & $41.66 \mathrm{gm}$ & $325 \mathrm{ml}$ & $250 \mathrm{ml}$ \\
\hline National Formulary of Unani Medicine & $31.25 \mathrm{gm}$ & $625 \mathrm{ml}$ & $250 \mathrm{ml}$ \\
\hline
\end{tabular}

For preparation of Sample 1 (Arka Prakash method) water was sprinkled over the leaves. The wet leaves were placed in round bottom flask of distillation apparatus and heating was started. The temperature was gradually increased up to $100^{\circ} \mathrm{C}$ and then reduce to $60^{\circ} \mathrm{C}$. This temperature was maintained throughout the procedure.

For preparation of Sample $2 \& 3$ (AFI \& NFUM), same method was followed for both, where Pudina leaves were slightly crushed and placed in round bottom flask with distilled water. It was placed over heating mantle and distillation apparatus was assembled. Receiver flask was marked up to the amount of Arka will be extracted. After marking and assembly, the mantle was started for heating, temperature was gradually increased up to $100^{\circ} \mathrm{C}$ and kept for 30 minutes then it was reduced to $50^{\circ} \mathrm{C}$ and was maintained throughout the procedure till appropriate quantity of Arka obtained. Then the Arka was preserved in air tight container and marked as Sample 2 (AFI) and Sample 3 (NFUM).

After preparation of $A r k a$, all the three samples were analyzed for organoleptic and physico-chemical characters i.e. $\mathrm{pH}$, Specific gravity \& refractive index in the Drug testing laboratory, Department of Rasashastra \& Bhaishajya Kalpana, NIA, Jaipur and the results were recorded.

\section{Results}

Arka Obtained:

Sample 1 (Arka Prakash) $7 \mathrm{ml}$; Duration: $60 \mathrm{~min}$.

Sample 2 (AFI) - $250 \mathrm{ml}$; Duration: $7 \mathrm{hrs}$.

Sample 3 (NFUM) - 250 ml; Duration: 7 hrs. 30 min.

Analytical tests

Table No.4 showing the physico-characters of 3 Arka Samples

\begin{tabular}{|l|l|l|l|}
\hline Character & Sample 1 (A.P.) & Sample 2 (AFI) & Sample 3 (NFUM) \\
\hline Color & Yellowish transparent & Transparent & Transparent \\
\hline Odour & Typical Mint like (Strong) & Typical Mint like & Typical Mint like \\
\hline Taste & Kashaya, Tikta (Strong) & Kashaya, Tikta & Kashaya, Tikta \\
\hline Appearance & Oily & Clear watery & Clear watery \\
\hline Clarity & Floating oil drops & Floating oil drops & Floating oil drops \\
\hline pH & - & 8.1 & 8 \\
\hline Specific Gravity & - & 1.002 & 0.997 \\
\hline Refractive index & - & 1.35 & 1.33 \\
\hline
\end{tabular}




\section{Discussion}

Number of dosages forms are described in traditional systems of medicine i.e. Ayurveda and Unani system of Medicine. These are planned because of a large number of drug from different origin (i.e. Plant, animal and mineral) and their properties. According to the properties of the drugs and purpose of medication the dosage form is selected. In Ayurveda, there are five fundamental dosage forms which are known as Panchavidha Kashaya Kalpana(13) i.e. Swarasa, Kalka, Kwatha, Hima, Phanta and other secondary dosage form. In Unani System of medicine Huboob-wa-Aqras, Jauhar, Kohal, Kushtajat, Majoon, Raughaniyat, Saiyyalat, Araq are some important dosage forms(14). Among these Hima, Phanta and Siyyalat are used for the drugs which are having volatile or aromatic matter as their active portion. But the problem with all these formulation are that these have to be taken instantly and now longer shelf life, sometimes these are difficult to swallow due to unpleased taste or appearance and higher dose. So considering all these the scholars developed Arka (or Araq) Kalpana, a unique dosage form for overcoming to all these problem. It is pleasant in appearance, odour and taste so palatability of the drug increases and the shelf life is also higher which is 6-12 months(15)' (16) or till the presence of Prashasta Arka properties(17). Although Arka Patana Yantra has been described in Arka Prakasha(18). But it is very complex to collect all its raw material and prepare it, so simple distillation apparatus was used for Arka preparation, that is very easy to assemble and at the same time it also provide sophistication too(19). It is much easier to mark it up to desired level and can be observed easily also. During preparation, in method of Arka Prakasha, where amount of water mentioned, was observe not enough for Arka extraction. Only sprinkling of water over the leaves has been said by the author that was found not enough to extract the Arka. Very less quantity of Arka was distilled by this method, so this method was looking not possible practically. Whereas in another two methods, sufficient quantity of Arka was obtained. While in comparison in between these two samples in amount of Arka obtained and their characters, the method of National Formulary of Unani Medicine was found better to drain maximum volatile matter and sufficient amount of $A r k a$. By looking towards the amount of the Arka to be drained, in classical method, it has described according to the time and Agni pramana (amount of heat), Arka has to be drained and parameters has not given according to the amount of the Arka. In today's era it's quite difficult to decide and carryout the distillation according to the Agni pramana (Amount of heating). As in the present date, various methods are more convenient and easy to control the heat during the process.

\section{Conclusion}

Arka Kalpana is an important dosage form for the drugs, are having volatile matter as their active ingredients. Arka Prakash has also mentioned Arka of some other drugs and indicated for various purposes, but in case of Pudina Arka, preparing method of Arka
Prakasha was found not much practically possible, negligible amount of Arka obtained by this method. While the method of Ayurveda Formulary of India and National Formulary of Unani medicine were found more convenient and practical for preparation of Pudina Arka. Among these method of NFUM was looking better according to ratio of ingredients, convenience during preparation, yield obtained, and characters of final product. It seems sufficient to extract the maximum amount of volatile oil in the final product. It is suggested for further research to evaluate the Arka on more sophisticated instruments and evaluate through preclinical and clinical studies.

\section{Acknowledgement}

Director \& Dean, National Institute of Ayurveda, Jaipur. HOD, all the teachers, scholars, all the team members, Department of Rasashastra \& Bhaishajya Kalpana, National Institute of Ayurveda, Jaipur, Rajasthan.

\section{References}

1. Sharma PV. Dravyaguna Vigyana, Part- II. Reprint edition. Varanasi, Chaukhambha Bharati Academy. 2011.395p.

2. Anonymous. Unani Pharmacopeia of India, Part- I, Volume- V, $1^{\text {st }}$ edition, Printed By Central Council of Unani Medicine, New Delhi, Published by Department of AYUSH, Ministry of Health of Family welfare, Government of India, on behalf of Government of India, Ministry of H \& FW., New Delhi. January 2008. 94-95p.

3. Anonymous. Ayurveda Sara Samgrah. Elahabad, Shree Baidyanath Ayurveda Bhawan. 2014. 645p.

4. Anonymous. Unani Pharmacopeia of India, Part- II, Volume- II, $1^{\text {st }}$ edition, Printed By Rekmo Press Pvt. Ltd., New Delhi, Published by Central Council of Unani Medicine, New Delhi, on behalf of Government of India, Ministry of Health \& Family Welfare (Department of AYUSH)., New Delhi. May 2010.7p.

5. Tripathi I. Arka Prakash of Lankapati Ravan. $4^{\text {th }}$ edition. Varanasi, Chowkhamba Krishnadas Academy; 2015. 22p.

6. Anonymous. The Ayurvedic Formulary of India, Part-I, Second revised English edition, Printed by National Institute of science communications and Information resources, CSIR, New Delhi on Behalf of Government of India, Ministry of Health and Family welfare, Department of Indian system of medicine \& Homeopathy, New Delhi, Published by The controller of Publications, New Delhi. 2003. $27 \mathrm{p}$.

7. Anonymous. National Formulary of Unani medicine, Part V, Printed by Central Council for Research in Unani Medicine, New Delhi, Published by Department of AYUSH, Ministry of Health and Family Welfare, Government of India on behalf of GOI, Ministry of H \& FW, New Delhi. July 2008. $137 \mathrm{p}$.

8. Anonymous. Ayurvedic Pharmacopeia of India, Part- I, Volume- V, First edition, Printed by 
National Institute of science communications and Information resources, CSIR, New Delhi on Behalf of Government of India, Ministry of Health and Family welfare, Department of AYUSH, New Delhi, Published by The controller of Publications, New Delhi. 2006. 144p.

9. Tripathi I. Arka Prakash of Lankapati Ravan. $4^{\text {th }}$ edition. Varanasi, Chowkhamba Krishnadas Academy; 2015. 22p.

10. Tripathi I. Arka Prakash of Lankapati Ravan. $4^{\text {th }}$ edition. Varanasi, Chowkhamba Krishnadas Academy; 2015. 14p.

11. Anonymous. The Ayurvedic Formulary of India, Part-I, Second revised English edition, Printed by National Institute of science communications and Information resources, CSIR, New Delhi on Behalf of Government of India, Ministry of Health and Family welfare, Department of Indian system of medicine \& Homeopathy, New Delhi, Published by The controller of Publications, New Delhi. 2003. $27 \mathrm{p}$.

12. Anonymous. National Formulary of Unani medicine, Part V, Printed by Central Council for Research in Unani Medicine, New Delhi, Published by Department of AYUSH, Ministry of Health and Family Welfare, Government of India on behalf of GOI, Ministry of H \& FW, New Delhi. July, 2008. $187 \mathrm{p}$.
13. Dr. Sharma RK \& Bhagwan DV. Charaka Samhita of Agnivesh, Sutra Sthana 4/7. Varanasi, Chowkhamba Sanskrit series. 2014. 84p.

14. Anonymous. National Formulary of Unani medicine, Part V, Printed by Central Council for Research in Unani Medicine, New Delhi, Published by Department of AYUSH, Ministry of Health and Family Welfare, Government of India on behalf of GOI, Ministry of H \& FW, New Delhi. July, 2008. $137 \mathrm{p}$.

15. Khan Foroz et.al, Accelerated Stability Study of Arq, Int. J. Pharm. Sci. Rev. Res., 52(1), September - October 2018; 1-6

16. (8)th point, Rule 161B, Drug \& Cosmetic Rules 1945 under The Drug and Cosmetics act 1940, updated and w.e.f. 12-8-2016

17. Tripathi I. Arka Prakash of Lankapati Ravan. $4^{\text {th }}$ edition. Varanasi, Chowkhamba Krishnadas Academy; 2015. 14p.

18. Tripathi I. Arka Prakash of Lankapati Ravan. $4^{\text {th }}$ edition. Varanasi, Chowkhamba Krishnadas Academy; 2015. 11-13p.

19. Simple distillation apparatus from Wikipedia, the free encyclopedia. [cited 2019, Jan $12^{\text {th }}$ ]. Available from https://en.wikipedia.org/wiki/ File:Simple_distillation_apparatus.svg. 